Kinestetik : Jurnal Ilmiah Pendidikan Jasmani 5 (1) (2021)

Kinestetik : Jurnal Ilmiah Pendidikan Jasmani

https://ejournal.unib.ac.id/index.php/kinestetik/index

DOI : 10.33369/jk.v5i1.14376

\title{
QUALITY OF PHYSICAL CONDITION OF YOUTH PENCAK SILAT ATHLETES REVIEWED FROM SPEED, POWER, AND STRENGTH
}

\section{Haris Nugroho ${ }^{1 *}$, Satria Yudi Gontara ${ }^{2}$, Prayogi Dwina Angga ${ }^{3}$, Gatot Jariono ${ }^{4}$, Inosen Lingsir Maghribi ${ }^{5}$}

${ }^{125}$ Sports Training Education, Faculty of Sports, Universitas Sebelas Maret, Surakarta, Indonesia

${ }^{3}$ Elementary School Teacher Study Program (PGSD), Teacher Training, and Education Faculty, Universitas Mataram, Mataram, Indonesia

${ }^{4}$ Sports Education, Teacher Training and Education Faculty, Universitas Muhammadiyah Surakarta, Sukoharjo, Indonesia

Article Info

Article History :

Received : February 2021

Revised : February 2021

Accepted : March 2021

Available online : March

2021

Keywords:

Pencak silat, Physical quality, power, speed, strength,

\begin{abstract}
The purpose of this study was to analyze the physical quality of youth pencak silat athletes in terms of speed, power and strength. The sample of this study was athletes Pencak silat category of young male and female numbered 40 people consisting of 20 male and 20 female. Sampling techniques use purposive samples because it considers the characteristics of age and gender. The quasi-experimental method with the quantitative approach used in this research, The constellation of this research is pretest-posttest one group design. Data analysis techniques use descriptive statistics and inferential statistics. Descriptive analysis aims to describe the characteristics of this research while inferential analysis using paired one sample test at a significant level $\alpha=0.05$, overall data analysis used is SPSS program version 20.0. The results of this study showed that the quality of physical condition of athletes in the youth competition category is reviewed from speed, power, and strength in the good category. However, in this study, the need to further identify anthropometrics, and psychology athletes to determine the achievements of adolescent martial arts match categories according to gender characteristics.
\end{abstract}

\footnotetext{
Corresponding address : Jl. Menteri Supeno, Manahan, Kecamatan

ISSN 2685-6514 (Online)

Banjarsari, Kota Surakarta

*Corresponding email : harisnugroho@staff.uns.ac.id

ISSN 2477-331X (Print)
} 


\section{INTRODUCTION}

One of the rich cultures of martial arts is Pencak silat (Kartomi, 2011). With a variety of geographical and ethnological situations and the development of the times experienced by the Indonesian nation, Pencak silat is formed by situations and conditions (Kumaidah, 2012). Nowadays Pencak silat we know with various forms and patterns but have the same aspects (Setiawan, 2011).

Pencak silat is the personality element of the Indonesian nation owned from the results of hereditary cultivation (Yulio Pratama \& Trilaksana, 2018). Until now there has been no manuscript or set on the history of self-defense of the Indonesian nation that is compiled naturally and can be accounted for and become a source for more orderly development (Kholis, 2016). Only hereditary and personal or group backgrounds and history of core selfdefense are spoken. The nature of the cover-up because it was formed by the colonial era in the past is an obstacle to development in which we are now demanding wider openness and awareness.

Observing the situation and conditions as stated earlier that, to maintain the culture, one of them is through scientific studies with the approach of science, technology, and sports. Advances in science or technology have an impact on various sports. Sophistication in the field of measurement and evaluation with the discovery of instruments that can be used to predict a person's achievements encourages sports coaches and coaches to work effectively in identifying and selecting talented athletes.

Training and nurturing athletes are not easy, but it takes a long journey from training to becoming an elite athlete. To train athletes must be supported from strategies, techniques, tactics, mental, characteristics of athletes judging by gender, anthropometric, physical condition, and related to improved achievement until becoming an elite athlete.

This study is only limited to the physical quality of young male and female athletes in the matching category reviewed from speed, power, and strength (Puspitasari, 2019; Royana, 2017; Subarjah, 2013). Physical quality is one of the main supports in all sports. It can be indicated that if the athlete has a good quality physical condition, then the athlete is not tired quickly and still has a qualified physical reserve to perform further physical activities as well as vice versa if the athlete does not have a good quality physical condition, then the athlete is quickly tired and does not have a qualified physical reserve to perform the next physical activity.

This is following the results of previous research that the quality of physical condition is one of the indicator requirements to improve athletes' achievements and as an early achievement, sport to become an elite athlete (Jariono et al., 2020; Jariono \& Subekti, 2020). To improve physical condition then all components consisting of strength, agility, endurance, speed, explosive power, flexibility, coordination, and a balance must be developed (Aidar et al., 2018; Anderson et al., 2015; Beltran-Valls et al., 2020; Moraes et al., 2019; Mutuku et al., 2013; Ohayon, 2005; Taylor et al., 2000). Physical condition in all sports is a physical ability that determines the achievements that are realized by individuals to achieve better achievements.

In the study choose the quality of physical condition, namely speed, power, and strength. Speed is a conditional 
activity carried out by a person to react quickly, and it is appropriate to travel a certain distance with the fastest possible time. This is supported by the results of research (Cronin \& Hansen, 2005; Fokkema et al., 2017; Haugen et al., 2014; Manning \& Hill, 2009; Sheppard et al., 2006) Speed movements are carried out against different resistances namely (weight, iron weight, water, and others) with the effect of the influence of strength is also a strength factor. Since speed frictions are carried out in the shortest possible time, the speed is directly at the time and the influence of force.

Power is a combination of strength and speed or maximum exertion of muscle force that concerns the strength and speed of dynamic and explosive muscle contractions, and by involving the ability of muscles to contract optimally and maximally in a short time (Cormie et al., 2011; Taber et al., 2016; Vanhatalo et al., 2011). that power can be influenced by two physical components namely strength and speed, that is, if a fighter is trained in strength and then trained in speed then automatically the power ability will increase.

Strength is an important motor component and is very necessary to increase muscle endurance in overcoming weight during sports activities (Ismanda et al., 2017; Rahman, 2019; Sahara et al., 2019). According to (Aagaard \& Andersen, 2010; Mach \& Fuster-Botella, 2017; Volek et al., 2015; Wilson et al., 2012) is a component of physical condition that concerns the problem of an athlete's ability when using his muscles to receive weights within a certain working time.

Pencak silat athletes if they have the good physical condition are indicated, able to do longer training activities, and do not feel tired quickly. In this study, physical condition quality training trained endurance, strength, agility, coordination, flexibility speed, strength, and balance. Based on this phenomenon, the purpose of this study was to examine the quality of the physical condition of young Pencak silat athletes in the men's and women's competition categories in terms of speed, power, and strength-based on gender characteristics.

\section{METHODS}

The method used in this research is quasi-experimental using the design of pretes_posttest one group design. The free variable is the quality of physical condition while the bound variable is speed, power, and strength. This study was conducted for 8 (eight) weeks by doing exercises 3 times in 1 week and training duration of 120 minutes per 1 exercise. Furthermore, in this research there are several steps taken, namely " (1) establish the research subject group; (2) pre-test $\left(\mathrm{O}_{1}\right)$; (3) To treat physical condition quality training; (4) Carry out post-test $\left(\mathrm{O}_{2}\right)$; (5) look for pre-test and post-test average scores and be compared between the two; (6) look for the difference between the two averages through the paired samples test (t_test) method "to determine whether or not there is a significant influence of the approach to the quality of physical condition of young male and female in the matching category of athletes reviewed from speed, power, and strength, by utilizing gender characteristics".

\section{Participants}

Athlete Pencak silat young male and female in the category of 14-17 years old who trained a total of 40 people consisting of 20 male and 20 female as a sample of research while appropriate this research was conducted at the Center for Education and Training Student Sports (PPLP) Pencak silat Jawa Tengah. 


\section{Sampling Procedures}

Sampling techniques using purposive sampling techniques. Because in this study considering gender and age, as well as the length of exercise at least, have followed the exercise 1 year.

\section{Materials and Apparatus}

Data collection techniques in this study used lower body and upper body treatment tests namely speed, power, and strength. (1) Speed lower body test using maximum speed test of acceleration of 30 meters while speed upper body test using hand speed test (2) power test for the lower body using triple hoop jump test while for power upper body using hand speed test, and (3) strength lower body using one leg squat test while for upper body using dynamometer handgrip test. The implementation of each treatment can be described as follows:

\section{Upper body test speed, power, and} strength

\section{a. Hand Speed Test}

The purpose of this test is to find out the speed of the hands of martial arts athletes. The equipment is the mattress, stopwatch, and tape meters. While the implementation is to Move hands as quickly as possible between 2 lines $90 \mathrm{~cm}$ away. Hands can't cross. Target 25 times in 15 seconds. The assessment is the score obtained by a record of the number of hand movements.

\section{b. Medicine ball Test}

The basketball throwing test is designed to measure the strength of the upper body. The assessment on the medicine ball throw test is to record the furthest distance that can be thrown by each test with a thoroughness level of about $5 \mathrm{~cm}$ ( measured from the base of the ball at the time of contact with the ground on the first reflection)

\section{c. Test handgrip dynamometer}

The purpose of this test is to measure the grip strength of the right and left hand. The assessment is the best grip strength score from two experiments, recorded as a score in units of $\mathrm{Kg}$. with a thoroughness level of $0.5 \mathrm{~kg}$ :

2. Lower body test speed, power, and strength

\section{a. Test run 30 meters}

The purpose of this test is to find out the maximum speed ability to run as Pencak silat athletes. As for the assessment is scored obtained with the fastest time record ranging from the signal 'yes' to the finish, each candidate is given a chance 3 times to take the best time.

b. Triple hoop jump test

The purpose of this test is to find out the power ability of the muscles of the limbs. For the way measurement is done with the provisions: (1) The measured result is a distance of 3 hops achieved from the right hop and the left hop (there are two results); (2) Distance result measured in units of $\mathrm{m}$ (with the accuracy of $0.01 \mathrm{~m}$ ); (3) the final distance is measured precisely on the heel of the third hop jump.

c. One leg squat test

The purpose of this test is to find out the ability of the lower body muscles that involve balance and coordination while the research is obtained with a score of 1 repetition.

\section{Procedures}

The procedures in this study are: (1) researchers conduct pretests to find out the initial ability of speed, strength, and strength before exercise about the quality of physical condition of youth martial arts athletes in the category of the match, (2) after pretest, then the sample trained using 
physical condition exercises for 8 weeks as many as 16 meetings in 1 week was treated as much as 3 times each afternoon with a duration of 120 minutes of training time, and (3) after the implementation of the study was carried out, then conducted posttest, to find out the increase in speed, power, and strength of athletes Pencak silat young male and female match categories.

\section{Design or Data Analysis}

Data analysis used in this study is to use t_test at a significant level of $\alpha=$ 0.05 to find out the difference between the effect of pretest and post_test speed, power, and strength. Overall, this data analysis uses SPSS version 20.0.

\section{RESULT}

\section{Descriptive analysis}

Descriptive analysis of data aims to draw distribution from "pretest and posttest " speed, power, and strength. A recap of the results of the descriptive analysis of data can be seen in the following table.

Tabel 1. Results of descriptive analysis "pretest and posttest" speed, power, and strength upper body and lower body of male and female athletes

\begin{tabular}{lcccc}
\hline \multirow{2}{*}{ Mean } & \multicolumn{3}{c}{ Upper and Lower Body } \\
\cline { 2 - 5 } & \multicolumn{2}{c}{ Male } & \multicolumn{2}{c}{ Female } \\
\cline { 2 - 5 } & Pre & Post & Pre & Post \\
\hline Hand speed & 54.40 & 61.95 & 51.35 & 54.80 \\
\hline $\begin{array}{l}\text { Medicine } \\
\text { ball }\end{array}$ & 6.70 & 8.89 & 7.19 & 8.89 \\
\hline Handgrip & 36.90 & 41.71 & 24.16 & 34.92 \\
\hline $\begin{array}{l}\text { Sprint 30 } \\
\text { meters }\end{array}$ & 4.54 & 3.97 & 5.16 & 4.29 \\
\hline $\begin{array}{l}\text { Triple hoop } \\
\text { jump }\end{array}$ & 10.38 & 13.90 & 7.66 & 10.46 \\
\hline $\begin{array}{l}\text { One leg } \\
\text { squat }\end{array}$ & 43.51 & 53.85 & 52.41 & 53.46 \\
\hline
\end{tabular}

Based on the results of the descriptive analysis in table 1 , it can be concluded that there is an increase in pretest and posttest speed using hand speed test, power using medicine ball test, and strength using handgrip test as a whole the treatment is done pad upper body test athletes Pencak silat male match category after being treated with physical condition quality training. Then for based on the results of the descriptive analysis in table 1, it can be concluded that there is an increase in pretest and posttest speed using sprint test 30 meters, power using triple hoop jump test, and strength using handgrip test as a whole the treatment is carried out pad lower body test athletes silat male and female match category after being treated with physical condition quality training.

\section{Prerequisite test}

The normality test is used as a prerequisite for a hypothesis test. The normality test uses Kolmogorov-Smirnov $\mathrm{Z}$ (KS-Z) test. Normality test requirement is normally distributed data if $\mathrm{KS}-\mathrm{Z} \geq$ $\alpha=0.05$ otherwise data is assumed not to be normal distribution if KS-Z $\leq \alpha=0.05$. The normality test can be seen in the following table:

Tabel 2. Normality test results "pretest and posttest" speed, power, and strength upper body and lower body of male athletes

\begin{tabular}{lcccc}
\hline \multirow{2}{*}{ Mean } & \multicolumn{3}{c}{ Upper and Lower Body } \\
\cline { 2 - 5 } & \multicolumn{2}{c}{ Male } & \multicolumn{2}{c}{ Female } \\
\cline { 2 - 5 } & Pre & Post & Pre & Post \\
\hline Hand speed & 0.990 & 0.264 & 0.582 & 0.291 \\
\hline $\begin{array}{l}\text { Medicine } \\
\text { ball }\end{array}$ & 0.736 & 0.878 & 0.719 & 0.495 \\
\hline Handgrip & 0.868 & 0.727 & 0.851 & 0.933 \\
\hline $\begin{array}{l}\text { Sprint 30 } \\
\text { meters }\end{array}$ & 0.934 & 0.877 & 0.934 & 0.877 \\
\hline $\begin{array}{l}\text { Triple hoop } \\
\text { jump }\end{array}$ & 0.225 & 0.219 & 0.225 & 0.219 \\
\hline $\begin{array}{l}\text { One leg } \\
\text { squat }\end{array}$ & 0.978 & 0.997 & 0.978 & 0.997 \\
\hline
\end{tabular}


Based on normality test results data pretest and posttest upper body "hand speed, medicine ball, and handgrip in normal distributed male athletes or KSZ> $\alpha=0.05$. Based on normality test results data "pretest and posttest " lower body sprint 30 meters, triple hoop jump, and one leg squat is normally distributed male and female athletes or KS-Z> $\alpha=$ 0.05 . Thus it can be concluded that the sample of this study as a whole both youth martial arts athletes in the male and female competing categories came from a normally distributed population. After the normality test is carried out, then hypothetical testing is carried out.

\section{Hypothesis test}

Tabel 3. Results t_test data "pretest and posttest" speed, power, and strength upper body and lower body of male athletes

\begin{tabular}{llll}
\hline \multirow{2}{*}{ pretest_posttest } & \multicolumn{3}{c}{$\begin{array}{c}\text { Upper Body and } \\
\text { Lower body }\end{array}$} \\
\cline { 2 - 2 } & $\mathbf{t}_{\text {-count }}$ & Sig & $\mathbf{t}_{\text {-table }}$ \\
\hline Hand speed & 4.953 & & \\
\hline Medicine ball & 3.151 & & \\
\hline Handgrip & 4.371 & \multirow{2}{*}{.000} & \multirow{2}{*}{1.729} \\
\hline Sprint 30 meters & 5.008 & & \\
\hline Triple hoop jump & 14.750 \\
\hline One leg squat & 6.114 & & \\
\hline
\end{tabular}

Based on analysis paired samples test (t_test) "pretest and posttest" speed, power, and strength upper body in table 3 above obtained t_count value of 4953, 3151, and 4371 and $t_{-}$table (19(10);0.05) respectively of 1,729 . Thus it can be concluded that the correlation coefficient (paired samples test (t_test) between pretest and posttest increases "pretest and posttest" hand speed, medicine ball, and handgrip significant male athletes or $\mathrm{H}_{0}$ rejected and received $\mathrm{H}_{1}$. This means that there is a significant influence of the quality of physical condition on the increase in speed, power, and strength upper body of athletes in the competition category. Then for based on analysis paired samples test (t_test) "pretest and posttest" speed, power, and strength lower body in table 3 above obtained the value of $t_{\text {ccount }}$ of $5,008,14,750$, and 6,114 and $t_{-}$table (19(10);0.05) of 1,729 . Thus it can be concluded that the correlation coefficient (paired samples test (t_test) between pretest and posttest improvement "pretest and posttest" sprint 30 meters, triple hoop jump, and one leg squat significant male athletes or $\mathrm{H}_{0}$ rejected and received $\mathrm{H}_{1}$. This means that there is a significant influence of the quality of physical condition on the increase in speed, power, and strength lower body athletes Pencak silat match category.

Tabel 4. Results t_test data "pretest and posttest" speed, power, and strength upper body of female athletes

\begin{tabular}{llll}
\hline \multirow{2}{*}{ pretest_posttest } & \multicolumn{2}{c}{$\begin{array}{c}\text { Upper Body and } \\
\text { Lower body }\end{array}$} \\
\cline { 2 - 2 } & $\mathbf{t}_{\text {-count }}$ & Sig & $\mathbf{t}_{\text {-table }}$ \\
\hline Hand speed & 11.376 & & \\
\hline Medicine ball & 6.913 & & \\
\hline Handgrip & 9.005 & \multirow{2}{*}{.000} & \multirow{2}{*}{1.729} \\
\hline Sprint 30 meters & 21.076 \\
\hline Triple hoop jump & 3.201 \\
\hline One leg squat & 6.322 & & \\
\hline
\end{tabular}

Based on analysis paired samples test (t_test) "pretest and posttest" speed, power, and strength upper body in table 4

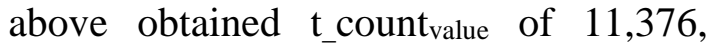
6913, and 9,005 and $t_{-}$table (19(10);0.05) respectively of 1,729 . Thus it can be concluded that the correlation coefficient (paired samples test (t_test) between pretest and posttest increase "pretest and posttest"hand speed, medicine ball, and handgrip significant female athletes or $\mathrm{H}_{0}$ rejected and received $\mathrm{H}_{1}$. This means that there is a significant influence of the quality of physical condition on the increase in speed, power, and strength upper body of athletes in the competition 
category. Then for based on analysis paired samples test (t_test) "pretest and posttest" speed, power, and strength lower body in table 4 above obtained the value of $t_{\text {_count }}$ of 21,076, 3,201, and 6,322 and $t_{\text {_table }}(19(10) ; 0.05)$ respectively of 1,729 . Thus it can be concluded that the correlation coefficient (paired samples test (t_test) between pretest and posttest improvement "pretest and posttest" sprint 30 meters, triple hoop jump, and one leg squat significant female athletes or $\mathrm{H}_{0}$ rejected and received $\mathrm{H}_{1}$. This means that there is a significant influence of the quality of physical condition on the increase in speed, power, and strength lower body athletes Pencak silat match category.

Coefficient as a whole both male and female athletes can be generalized or can apply to the overall population of athletes Pencak silat match category where a sample of 40 people taken, consisting of 20 male samples and 20 female samples.

\section{DISCUSSION}

This study resulted in a significant influence on the quality of physical condition of adolescent martial arts athletes to theories of men and women's competition reviewed from "pretest and posttest" speed, power, and strength measured from the upper body and lower body. Never, athletes, this exercise uses only one exercise about the quality of the physical condition. It is recommended that you use other exercises as an indicator to increase speed, power, and strength.

Research on improving the components of the physical condition through the approach of exercise is carried out by many sports players or academics in the field of sports. But it is still limited to researching about improving physical condition only. One of them is research conducted (Wahyudi, 2018) on the influence of high-intensity interval training (HIIT) and circuit training on speed, agility, and muscle strength of the limbs. The results of this study suggested that there is a significant influence of HIIT exercises on increased speed, agility, and muscle strength of the limbs. Another study was conducted by (Kuswanto, 2016) on the preparation of physical tests of adult Pencak silat athletes in the macing category. The research, which resulted in physical test guidelines for adult martial arts athletes in the matching category reviewed the validity and reliability that can be used to measure the physical condition of adult martial arts athletes in the matching category.

A fundamental difference in the research that the researchers conducted was that physical quality exercise was reviewed from speed, power, and strength according to gender characteristics.

\section{CONCLUSION}

The results of this study can be concluded that there is a significant influence. Thus in this study the need to be carried out further to identify anthropometrics, environments, techniques, strategies, and psychology athletes to determine the achievements of adolescent martial arts match categories following gender characteristics. 


\section{ACKNOWLEDGEMENT}

Thank you to Sebelas Maret University Surakarta for providing the opportunity to conduct research and PPLP Pencak Silat Jawa Tengah has facilitated and helped researchers in collecting data on this research.

\section{REFERENCES}

Aagaard, P., \& Andersen, J. L. (2010). Effects of strength training on endurance capacity in top-level endurance athletes. In Scandinavian Journal of Medicine and Science in Sports. https://doi.org/10.1111/j.16000838.2010.01197.x

Aidar, F. J., Gama De Matos, D., De Souza, R. F., Gomes, A. B., Saavedra, F., Garrido, N., Carneiro, A. L., \& Reis, V. (2018). Influence of aquatic exercises in physical condition in patients with multiple sclerosis. Journal of Sports Medicine and Physical Fitness. https://doi.org/10.23736/S00224707.17.07151-1

Anderson, D., Moggridge, H., Warren, P., \& Shucksmith, J. (2015). The impacts of "run-of-river" hydropower on the physical and ecological condition of rivers. Water and Environment Journal. https://doi.org/10.1111/wej.12101

Beltran-Valls, M. R., Camarero-López, G., Beltran-Garrido, J. V., \& CeciliaGallego, P. (2020). Effects of a Tapering Period on Physical Condition in Soccer Players. Journal of Strength and Conditioning Research. https://doi.org/10.1519/JSC.000000000 0002138

Cormie, P., McGuigan, M. R., \& Newton, R. U. (2011). Developing Maximal Neuromuscular Power. Sports Medicine. https://doi.org/10.2165/11538500000000000-00000

Fokkema, T., Kooiman, T. J. M., Krijnen, W. P., Van Der Schans, C. P., \& De Groot, M. (2017). Reliability and validity of ten consumer activity trackers depend on walking speed. Medicine and Science in
Sports and Exercise. https://doi.org/10.1249/MSS.00000000 00001146

Haugen, T. A., Tønnessen, E., Hisdal, J., \& Seiler, S. (2014). The role and development of sprinting speed in soccer. In International Journal of Sports Physiology and Performance. https://doi.org/10.1123/IJSPP.20130121

Ismanda, S. N., Purba, A., \& Herman, H. (2017). Efektivitas Latihan Tahap Persiapan Khusus terhadap Endurance Atlet Pria Junior Cabang Olahraga Taekwondo. Jurnal Terapan Ilmu Keolahragaan. https://doi.org/10.17509/jtikor.v2i2.807 1

Jariono, G., \& Subekti, N. (2020). Sports Motivation Survey And Physical Activity Students Of Sport Education Teacher Training And Education Faculty FKIP Muhammadiyah University Surakarta. Kinestetik: Jurnal Ilmiah Pendidikan Jasmani. https://doi.org/10.33369/jk.v4i2.12449

Jariono, G., Subekti, N., Indarto, P., Hendarto, S., Nugroho, H., Fachrezzy, F., Surakarta, U. M., Sebelas, U., Surakarta, M., \& Jakarta, U. N. (2020). Analisis Kondisi Fisik Menggunakan Software Kinovea Pada Atlet Pendahuluan. 16(2), 133-144.

Kartomi, M. (2011). Traditional and modern forms of pencak silat in Indonesia: The suku mamak in Riau. Musicology Australia.

https://doi.org/10.1080/08145857.2011. 580716

Keolahragaan, S. I., Olahraga, F. I., \& Jakarta, U. N. (2021). Pelatihan dan Penyusunan Latihan Fisik Pada Anggota Komando Strategis Angkatan Darat ( KOSTRAD ). 1(1), 27-34. https://doi.org/10.25008/altifani.v1i1.11 5

Kholis, N. (2016). Aplikasi Nilai-Nilai Luhur Pencak Silat Sarana Membentuk Moralitas Bangsa. Jurnal SPORTIF: Jurnal Penelitian Pembelajaran. https://doi.org/10.29407/js_unpgri.v2i2. 508

Kumaidah, E. (2012). Penguatan Eksistensi 
Bangsa Melalui Seni Bela Diri Tradisional Pencak Silat. Jurnal Humanika.

Kuswanto, C. W. (2016). Penyusunan tes fisik atlet pencak silat dewasa kategori tanding. Jurnal Keolahragaan. https://doi.org/10.21831/jk.v4i2.6423

Mach, N., \& Fuster-Botella, D. (2017). Endurance exercise and gut microbiota: A review. In Journal of Sport and Health Science. https://doi.org/10.1016/j.jshs.2016.05.0 01

Moraes, D. C., Lenardt, M. H., Seima, M. D., Mello, B. H. de, Setoguchi, L. S., \& Setlik, C. M. (2019). Postural instability and the condition of physical frailty in the elderly. Revista Latino-Americana de https://doi.org/10.1590/15188345.2655-3146

Mutuku, F. M., Khambira, M., Bisanzio, D., Mungai, P., Mwanzo, I., Muchiri, E. M., King, C. H., \& Kitron, U. (2013). Physical condition and maintenance of mosquito bed nets in Kwale County, coastal Kenya. Malaria Journal. https://doi.org/10.1186/1475-2875-1246

Puspitasari, N. (2019). Faktor Kondisi Fisik Terhadap Resiko Cedera Olahraga Pada Permainan Sepakbola. Jurnal Fisioterapi Dan Rehabilitasi. https://doi.org/10.33660/jfrwhs.v3i1.34

Rahman, N. A. (2019). Model Latihan Untuk Mengembangkan Biomotor Endurance Pesilat Remaja. Musamus Journal of Physical Education and Sport (MJPES). https://doi.org/10.35724/mjpes.v1i2.114 9

Royana, I. F. (2017). Analisis Kondisi Fisik Pemain Tim Futsal Upgris. Jendela Olahraga. https://doi.org/10.26877/jo.v2i2.1860

Sahara, M. P., Widyastuti, N., \& Candra, A. (2019). Kualitas Diet dan Daya Tahan (Endurance) Atlet Bulutangkis Remaja Di Kota Semarang. Journal of Nutrition College. https://doi.org/10.14710/jnc.v8i1.23810

Setiawan, I. (2011). Eksistensi Seni Pencak Silat di Kabupaten Purwakarta (Kajian tentang Strategi Adaptasi). Patanjala:
Jurnal Penelitian Sejarah Dan Budaya. https://doi.org/10.30959/patanjala.v3i3. 254

Subarjah, H. (2013). Latihan Kondisi Fisik. Educacion.

https://doi.org/10.1017/CBO978110741 5324.004

Taber, C., Bellon, C., Abbott, H., \& Bingham, G. E. (2016). Roles of maximal strength and rate of force development in maximizing muscular power. Strength and Conditioning Journal. https://doi.org/10.1519/SSC.000000000 0000193

Vanhatalo, A., Jones, A. M., \& Burnley, M. (2011). Application of critical power in sport. In International Journal of Sports Physiology and Performance. https://doi.org/10.1123/ijspp.6.1.128

Volek, J. S., Noakes, T., \& Phinney, S. D. (2015). Rethinking fat as a fuel for endurance exercise. European Journal of Sport Science. https://doi.org/10.1080/17461391.2014. 959564

Wahyudi, A. N. (2018). Pengaruh Latihan High Intensity Interval Training (Hiit) dan Circuit Training Terhadap Kecepatan, Kelincahan, dan Power Otot Tungkai. JSES : Journal of Sport and Exercise Science. https://doi.org/10.26740/jses.v1n2.p4756

Wilson, J. M., Marin, P. J., Rhea, M. R., Wilson, S. M. C., Loenneke, J. P., \& Anderson, J. C. (2012). Concurrent training: A meta-analysis examining interference of aerobic and resistance exercises. Journal of Strength and Conditioning Research. https://doi.org/10.1519/JSC.0b013e318 $23 \mathrm{a} 3 \mathrm{e} 2 \mathrm{~d}$

Yulio Pratama, R., \& Trilaksana, A. (2018). Perkembangan Ikatan Pencak Silat Indonesia (IPSI) Tahun 1948-1973. Avatara. 